\title{
Nas Asas da Pandemia: Uma Entrevista com Silvio Tendler
}

\author{
Jorge de La Barre, Lucas do Amaral Afonso e Alan Gomes Freitas ${ }^{1}$
}

UFF, Rio de Janeiro, Brasil

\begin{abstract}
Entrevista realizada online entre junho e julho de 2020. O cineasta fala sobre a situação pandêmica, as maneiras que ele encontrou de manter-se na ativa nesse periodo de distanciamento social. Tendler está "inventando outro cinema", a partir da coleta cotidiana e incansável, de uma matéria prima inovadora, feita pelo aplicativo Whatsapp. Forma de produção cinematográfica que o documentarista carioca denomina de Cinezap, ou o cinema produzido em tempos de "cinemia", como ele também cunhou. Tendler ainda fala dos temas a serem tratados, sempre com "dedo na ferida", e adianta, com detalhes sobre seus atuais projetos de cinema.

Palavras-chave: cinema, confinamento, distanciamento social, pandemia, Silvio Tendler
\end{abstract}

\section{Nas asas da pandemia: uma entrevista com Silvio Tendler}

"Sonhamos utopias, vivemos barbárie..." Assim inicia o documentário de Silvio Tendler, Utopia e Barbárie, um trabalho que durou aproximadamente 19 anos, considerado por Eduardo Escorel (2010), "uma colcha de retalhos", pois remonta um contexto geopolítico mundial do século $\mathrm{XX}$, analisado e interpretado pelo cineasta carioca. Silvio Tendler tem mais de 70 filmes em seu repertório; é responsável pela produção de documentários históricos como: Os Anos JK - Uma trajetória politica (1980), Jango (1984), Glauber - O Filme (2003), dentre outros. ${ }^{2}$ Sua trajetória no cinema é iniciada pela participação

1 Contato dos autores: jorgelabarre@id.uff.br; lucasafonso@id.uff.br; allan.difusao@gmail. com

2 Os filmes citados se encontram nas referências. 
no Movimento Cineclubista na década de 1960, no qual em 1968 assume a presidência da Federação de Cineclubes do Rio de Janeiro. No início da década de 1970, se muda para a França, onde inicia uma graduação em História. Essa fase resultou em contatos frutíferos à trajetória de historiador e cinematográfico de Silvio Tendler, que trabalhou com Jean Rouch, Joris Ivens e Chris Marker. E teve o diploma assinado por Marc Ferro, Jacques Le Goff e Charles Bettelheim. Em 1976, conclui o Mestrado em Cinema e História pela École des Hautes Études / Paris VII - Sorbonne.

No mesmo ano, retorna ao Brasil e dá início à realização de seu primeiro longa-metragem, Os anos JK (concluído em 1980). Em 1977, conduz um curso de Cinema e História na PUC-Rio, universidade à qual é integrado ao corpo docente desde 1979. Em 1987, produz Memória do Aço. Silvio Tendler produz diversos longas-metragens, que passam por temas tão diversos como: golpes de Estado, democracia, cultura popular brasileira, políticas de desenvolvimento nacional, geografia política do capitalismo, globalização, memória e história, produção e comercialização de alimentos, privatizações, quilombos, retratos de cineastas, artistas brasileiros, e outros. Porém, visto como um todo, o trabalho de Silvio Tendler se destaca numa particularidade: a arte de colocar, digamos, o "dedo na ferida" - título, aliás, de um dos seus documentários, que saiu em 2018.

No mesmo ano, em 8 de novembro, Silvio Tendler era convidado para participar da Mesa de abertura do VII Seminário Fluminense de Sociologia sob o tema "1968... 50 anos depois: cultura, mídia, imagens", com a presença de Eliska Altmann (IFCS/UFRJ), Luis Carlos Fridman (PPGS/UFF) e mediação de Jorge de La Barre (PPGS/UFF). Após a mostra do seu famoso documentário Utopia e Barbárie na sala Cine Arte da UFF, ficamos, Lucas e Jorge, a conversar com o diretor, que nos convidou para a casa dele algum dia para tomar chá e continuarmos a conversa. O tempo passou, e só conseguimos continuar a conversa bem mais tarde, já em plena pandemia devido ao Coronavírus. O encontro aconteceu de modo virtual, portanto o chá ficou para uma próxima vez. Devido a problemas de acesso à internet, o nosso primeiro encontro do 30 de junho de 2020 teve de ser interrompido - azares da nossa vida remota nesses tempos de pandemia! De repente, marcamos um segundo encontro logo em seguida, no dia 6 de julho.

"Vá à União Soviética pela Panam" - é como Silvio Tendler começa, na primeira parte da entrevista, a descrição do filme Nas Asas da Panam. O letreiro fazia parte de um cartaz de uma agência de turismo que anunciava a viagem para o interior da Rússia. Assim como Walter Benjamin exemplifica, a imagem dialética de um cartaz escondido por anos no "solo" de sua "consciência" e resgatado pelo letreiro "Sal de Bullrich" (Benjamin, 2009: 210), Silvio Tendler retoma, na entrevista que segue, a história de suas principais produções cinematográficas, por meio da narrativa autobiográfica. O cineasta lembra que o filme Utopia e barbárie não tem ponto final, assim, parte dessa obra se torna matéria prima para o filme autobiográfico de Tendler. Nas Asas da Panam foi lançado na Cinemateca do MAM, no dia 12 março de 2020, literalmente na 
véspera do primeiro confinamento devido à pandemia do Coronavírus. O filme é por assim dizer, praticamente inédito. Na presente entrevista, Silvio Tendler fala sobre os rumos de Nas Asas da Panam, e volta sobre as suas obras anteriores.

O "cineasta dos sonhos interrompidos" ("Biografia") fala também sobre a situação pandêmica pela qual estamos passando vai já quase um ano, as maneiras que ele encontrou de manter-se na ativa nesse periodo de distanciamento social. Tendler está "inventando outro cinema", a partir da coleta cotidiana e incansável, de uma matéria prima inovadora, feita pelo aplicativo Whatsapp. Forma de produção cinematográfica que o cineasta carioca denomina de Cinezap, ou o cinema produzido em tempos de "cinemia", como ele também cunhou. Tendler ainda trata dos temas, sempre com "dedo na ferida", e adianta, com detalhes exclusivos, sobre seus atuais projetos de cinema. ${ }^{3}$

\section{Primeiro encontro, 30 jun. 2020}

Lucas: Silvio, então. Gostaria já de início que você pudesse falar um pouco sobre o seu último trabalho, Nas Asas da Panam.

Silvio Tendler: Nas Asas da Panam é um filme que eu levei muitos anos fazendo. Que eu comecei a fazer em $1989 \mathrm{com}$ o fim, quando o muro de Berlim desmoronou e começou o fim do chamado socialismo real. Não que eu fosse a favor de muros, mas eu fui adestrado, eu fui criado, eu me criei pra viver no mundo futuro socialista. E com o fim da União Soviética - que foi em 1991 -, e com o fim de todo o bloco soviético, nós começamos a viver o mundo que, como o Professor Milton Santos falou, terminou contraditório. Quando você tinha o mundo socialista e o mundo capitalista, dava pra você ir por um terceiro caminho, que foi o terceiro mundo, que foi criado na Conferência de Bandungue em 1954. E com o fim do mundo socialista, o mundo ficou dividido entre países desenvolvidos e países dependentes, e aí as coisas ficaram dificeis. Então, a partir de 1989, eu votei pela primeira vez aos trinta e nove anos para Presidente da República. Eu deveria ter votado em 1970, com vinte anos, e só votei aos trinta e nove em 1989. E, ainda por cima, depois de tantos anos sem votar, a minha geração que votava pela primeira vez, escolheu o pior. Tinham mais de onze candidatos para Presidente da República, e eles votaram no Collor. Então foi uma decepção, foi um baque muito grande e o baque do socialismo real também. Então eu comecei a pensar e digerir o que

3 Por motivos editoriais, vários trechos da entrevista original, de quase 12.000 palavras, tiveram que ser cortados. Na versão atual, a entrevista foca nos aspetos relativos à produção cinematográfica de Silvio Tendler durante a pandemia. Participaram da entrevista: Jorge de La Barre, Professor do Programa de Pós-Graduação em Sociologia da Universidade Federal Fluminense (PPGS-UFF), Lucas do Amaral Afonso, doutorando pelo Programa de PósGraduação em Sociologia da Universidade Federal Fluminense (PPGS-UFF), e Alan Gomes Freitas, mestrando do Programa de Pós-graduação em Cinema e Audiovisual da Universidade Federal Fluminense (PPGCINE - UFF). 
seria o Utopia ou Barbárie. Então eu estava trabalhando e trabalhei o Utopia e Barbárie esses anos todos. Em 1994, mais ou menos, eu estava passando por uma agência de turismo no Rio de Janeiro e vi um cartaz, era uma igreja secular na antiga União Soviética e em baixo do cartaz estava escrito: União Soviética e Panam. E aí a URSS veio para durar um milénio. A Panam era a nave mãe que em 2001, no Kubrick, levaria a primeira tripulação para o espaço, era o avião da Panam. E os dois acabaram antes do final do século. E eu me vi com a igrejinha. Sobramos eu e a igreja, porque a União Soviética acabou, a Panam acabou e aí ficamos nós dois sozinhos no mundo. Então eu comecei, neste momento, a fazer um subproduto que era o Nas Asas da Panam. Nasceu mais ou menos em 2004. Eu fui fazendo ele, em 2010 eu consegui terminar o Utopia e Barbárie, apresentei e comecei a trabalhar o Nas Asas da Panam com as sucatas do Utopia e Barbárie e com a minha história pessoal. E aí esse filme ficou pronto em março de 2020, mais ou menos uns dez anos sendo feito, juntando coisas, acumulando fotografias em álbuns de família, recorte de jornal, pedaço de filme. Em 2020 ele ficou pronto e só teve uma sessão, no dia 12 de março de 2020, quando eu fiz uma grande festa no Museu de Arte Moderna para comemorar os meus setenta anos. Ele foi apresentado na Cinemateca, que foi onde eu me formei cineasta, na Cinemateca do MAM. $\mathrm{E}$ aí ele foi apresentado em uma única sessão, cento e poucas pessoas são testemunhas de que o filme existe, e dois dias depois fechou tudo. No dia 14 de março nós entramos em quarentena e estou até hoje, nós já estamos no dia 30 de junho, já estamos no último mês de junho, de quarentena desde o dia 14 de março. E é um filme que é muito bom, foi muito gostoso, a sessão foi muito maravilhosa. Já havia rumores do Coronavírus, mas nós ainda não tínhamos certeza. Então, as pessoas foram à festa, se beijaram, se abraçaram, comemoraram e, graças a Deus, na festa ninguém pegou Coronavirus. Mas depois cada um foi pra sua casa, e estou trancado desde lá. E nasceu Nas Asas da Panam que eu resisto de disponibilizar na internet, estou guardando ele para algum festival. Estou na esperança de que vai abrir e que a vida vai voltar ao normal.

Jorge: Agora parece que entramos "nas asas da pandemia”, né?

Silvio: "Nas asas do pandemônio", né?

Jorge: E aí não sabemos até quanto tempo, né?

Silvio: Mas na verdade estamos na pandemia hoje que não é na verdade uma pandemia, é um fenômeno chamado "cinemias". Porque é conveniente para humanidade falar da pandemia porque o Coronavírus atinge todo mundo e todos somos vítimas, mas existe duas outras pandemias já e que ninguém comenta nada: a fome e a obesidade. Hoje há má alimentação, as pessoas são gordas não é porque elas comem muito, é porque elas comem mal, comem produtos industrializados. E do outro lado as pessoas passando fome. Então estamos vivendo, ao mesmo tempo, essas três "cinemias". E junto com essas três "cinemias" nós estamos vivendo várias crises humanitárias com os refugiados europeus, os refugiados africanos, árabes, fugindo para Europa. 
As guerras provocadas pelas disputas religiosas. Então junta tudo isso ao Coronavírus e nós estamos em um pandemônio e não apenas vítimas de um vírus, estamos vítimas de um processo político que o mundo já vem vivendo há algum tempo.

Ironicamente ou não, a primeira entrevista acaba aqui, devido a problemas de conexão internet...

\section{Segundo encontro, 6 jul. 2020}

Lucas: Você disse que está inventando um novo cinema. Eu gostaria que você falasse um pouco disso, por favor.

Silvio: Sim, eu acho que o dever do cineasta - eu sou daquela corrente que gosta de inventar. [...]. Eu sou da escola de cinema que acha que o cinema não tem formulário padrão. Então, você não tem que fazer um filme... Você não olha um filme e reconhece um estilo, porque são todos iguais. Eu tento inventar, reconstruir, desconstruir e vou fazendo cinema assim. Então, quando todo mundo queria fazer cinema em $35 \mathrm{~mm}$, com muitos equipamentos sofisticados, eu trabalhava com $16 \mathrm{~mm}$. Depois, eu fui trabalhar com vídeo. Depois, eu fui fazer digital, e fui fazendo as coisas, que eu vou aprendendo as linguagens e as tecnologias. Eu acho que eu estou formulando agora, que eu falei esses dias, que o cinema é fruto de uma ética, de uma estética e de uma técnica; e isso varia de filme para filme, momento para momento. Então, se você pegar a história do cinema, você vai ver isso ao longo dos anos, quer dizer, você tem o cinema silencioso, aí, depois do cinema silencioso aparece o som no cinema. Alguns tentam não aderir e o comércio não permite: ou você adere ou você sucumbe. A tecnologia te obriga às mutações estéticas, porque a introdução do som no cinema é uma técnica, mas também, é uma estética nova. Você lutar por uma ideia num determinado momento e no momento seguinte lutar por uma outra ideia, é uma revolução ética: você tem que mudar a ética em função das circunstâncias que você está vivendo. As pessoas, agora me perguntam: "Mas, como é que você consegue filmar durante o governo Bolsonaro?" Aî, eu digo: "Difícil é você filmar durante o governo Bolsonaro como eu fiz durante a ditadura. Eu fiz o Jango, o JK, em plena ditadura militar. O JK era AI-5, o Jango, quando eu terminei, ainda era o governo federal Figueiredo. Seria muito fácil fazer durante uma democracia. Difícil, é você fazer durante uma ditadura. Filmar agora, no governo Bolsonaro, é que é o nosso desafio. [...]. Eu continuei filmando durante o governo Bolsonaro. O governo Bolsonaro começou em 2019. Eu estava filmando e fazendo filmes, e continuei fazendo. E aí, o Bolsonaro começou a sacanear os artistas, fazer a censura econômica, cortar todos os tipos de financiamento da universidade, da arte, da educação, da ciência, da tecnologia, da saúde. Ele começou a desmantelar o país. Eu falei: "Agora é o momento de filmar essas coisas". E então, eu estou fazendo um filme sobre o Sistema Único de Saúde, fazendo um filme sobre a Justiça, fazendo um filme sobre o mundo futuro, e fazendo 
um filme sobre sindicalismo: coisas fundamentais. E eu estava fazendo esses filmes, e estava fazendo outros dois, ainda oriundos da ANCINE. Estava fazendo um filme sobre o Chico Mário, que é um músico, irmão do Henfil e do Betinho, que morreu de AIDS aos 39 anos porque ele era hemofílico, e estava fazendo um filme sobre a arte urbana e os artistas de rua. Veio a pandemia, os artistas de rua tiveram que sair. O do Chico Mário estava quase pronto. A minha equipe foi toda para dentro de casa, ninguém ia sair, está todo mundo trancado. Aí, nós vamos continuar filmando por internet. E aí, eu tinha uma assistente meio careta. Foi aí que eu falei que nós, não temos formulário padrão. Nós estamos filmando em estúdio - tem uma salinha que eu aluguei como estúdio, que tem chroma key, ${ }^{4}$ tem fundo preto e tal, tudo para se trabalhar com bons recursos. E eu falei: "Não, nós vamos fazer por internet, nós vamos fazer por videoconferência. Vamos abrir uma sala, e vamos entrevistar as pessoas, por videoconferência." E começamos a fazer esses filmes todos e sem limites, sem limites. Os filmes que eu faço são filmes de verdade. Eu entrevistei ex-Ministro da Saúde, ex-Presidente da CUT, entrevistei o Ken Loach, que é um dos maiores cineastas do mundo. Então, eu continuei trabalhando normalmente, com esse veículo que nós estamos usando agora, que é a videoconferência. E aí, eu resolvi radicalizar mais ainda, e resolvi fazer cinema por Whatsapp. Então eu estou inventando o Cinezap! Eu abri dentro do meu Whatsapp uma página, uma pasta, e vou recolhendo tudo o que me mandam. Então, todo mundo, todo dia, ninguém manda menos de 5, 6 mensagens por dia. Eu me relaciono com umas 200 pessoas. Eu recebo, por dia, mais de 1000 mensagens que variam, segundo o estado de humor das pessoas. Pode ser uma piada, pode ser uma música, pode ser um desabafo triste, pode ser um discurso político... Eu recebo tudo, vou creditando de quem veio, e eu vou poder fazer um filme, um estudo psicológico durante a pandemia, todo ele feito com Whatsapp. E aí, eu vou discutir a questão que é fundamental para mim hoje, que é a questão dos direitos. As coisas que circulam por Whatsapp não têm direitos, todo mundo circula livremente, e eu também não vou vender esse filme, eu vou dar, vou botar a serviço da humanidade, então não vai ter direitos. E aí, eu estou inventando o Cinezap, que eu acho que é o cinema do futuro, porque todo mundo vai ter que continuar falando, e o que eu acho que é importante num longa-metragem, é dar nexo às ideias, entendeu? Então, porque que eu faço filmes longa-metragem? Porque você faz um curta, ele é sintético, ele tem uma ideia legal, ele é bom, ele pode ser um manifesto, mas para você explicar uma coisa, você tem que fazer um longa. Porque você tem que buscar a causalidade das coisas. Então, por isso, eu fiz Utopia e Barbárie; Encontro com Milton Santos; Castro Alves; Marighella; JK; Jango... E cada filme é uma realidade, que aborda um tema, e que você termina de ver aquele filme, você pode concordar ou pode discordar, mas seguramente você vai dizer, "Agora eu entendi", e aí você vai me dizer se você gostou ou não gostou, e se você concorda ou não concorda. Abre o debate. É isso.

4 Chroma key é uma técnica de produção de efeito visual que tem como objetivo manipular a imagem de fundo de um determinado objeto (NdE). 
Jorge: Silvio, posso fazer uma pergunta um pouco nessa continuação daquilo que você acabou de falar, em relação ao Cinezap? Eu achei muito interessante, mas eu queria te perguntar em relação precisamente aos documentários que você tem feito sobre um personagem, por exemplo o Jango, o JK, o Milton Santos... e agora com o zap, com o Whatsapp, é uma profusão de clipes, como você falou né, da charge, dos textos... é uma profusão. Então qual é, qual seria essa realidade que você iria filmar? Acho muito interessante, mas é um desafio enorme! Até o próprio humano não consegue, às vezes, dar conta de todas as mensagens que ele vai receber pelo zap, né?

Silvio: Então, você tem que pesquisar um autor ítalo-americano chamado Emile de Antonio. Ele fez um filme chamado No Ano do Porco; In the Year of the Pig, sobre a Guerra do Vietnã, e ele, já naquela época, fala disso. Ele fala: "Você pega o cinejornal, desconstrói o cinejornal, constrói uma outra matéria, e dá um outro formato e vira outra coisa." Isso, ele já fala nos anos 60, entendeu? E o cinema que eu faço é isso. Todos os meus filmes - JK, Jango, Marighela -, eu pego um tipo de material que foi feito com um propósito - o material do Jango, do JK, por exemplo -, tem muito cinejornal que era institucional, e eu descontruo a imagem institucional, para retrabalhar dando outro sentido histórico. Agora, com o zap, ficou mais fácil, porque a quantidade de material que me chega na mão é muito grande. Eu, agora, não preciso mais sair da minha mesa para receber esse material. Antigamente, eu tinha que ir a arquivos que ficavam mal guardados, mal iluminados, úmidos, estragando... Hoje, eu recebo 1000 temas por dia. Eu recebo os motoboys que estão em revolta, eu recebo os enfermeiros que estão em revolta, um filme que me mostra o sistema privado de saúde... E aí, eu mostro que o povo não tem acesso àquilo; desconstruo aquela imagem, reutilizo e reconstruo de outra forma. Então isso daí, o zap vai facilitar a minha vida. Tudo que eu fiz com Jango, JK, Marighella, Milton Santos, agora é sem sair da mesa. Fico sentado aqui no computador, e está tudo aqui na minha frente. Eu, hoje, recebi pelo menos 10 músicas diferentes de pessoas diferentes. Eu recebi 300 piadas, umas a favor, outras contra - outras, nem tanto. Recebi discursos políticos... E dá para você fazer uma subversão com isso. Hoje, me chamaram para assistir uma live ${ }^{5} \mathrm{de}$ um determinado político, e aí eu falei para a pessoa que me convidou: "Mas esse cara é muito chato!", aí, a pessoa começou a rir e vira outra coisa, entendeu? A pessoa que te convida para um ato politico começa a rir, dizendo: "É mesmo, esse cara é muito chato!" Entendeu? Então, você tem uma outra substância, um outro material. É uma desconstrução. E isso daí, é o Cinezap, que vai facilitar a minha vida, a tua vida, e a de vocês. Todo mundo aqui dessa sala. Daqui a pouco tempo, estará fazendo Cinezap, porque é uma revolução.

Jorge: Sim. É, eu acho muito interessante fazer esse trabalho de recuperação e da subversão, né? E aí, eu estou pensando em um filme chamado Redacted, de Brian de Palma. Fez um filme baseado em imagens da televisão, do noticiário... E ele faz uma outra narrativa, a partir das imagens sobre a

5 Live: sem dúvida, a expressão reflete os tempos pandêmicos atuais, e a multiplicação dos encontros virtuais - debates, conferências, aulas, shows... (NdE). 
Guerra do Iraq, no caso. Mas, hoje em dia, com essa plenitude de informações, você iria construir uma narrativa alternativa, é isso?

Silvio: Sim.

Jorge: Ou você iria destruir, desconstruir todas essas fontes para criar uma outra história?

Silvio: Quem desmantela para não colocar nada no lugar é o Bolsonaro, porque ele tem interesse em destruir o mundo que a gente vive para entregar de bandeja para as superpotências. A gente tem a obrigação de construir pensamentos, não é? Nós somos intelectuais, a gente tem que discutir. Eu venho da escola do Milton Santos, do Josué de Castro, do Darcy Ribeiro... Eu venho de uma escola que constrói pensamentos, então eu quero fazer um filme que te leve a pensar, e não um filme que te adormeça, né? E aí, o meu cinema vai te propor alternativas. Não significa, com isso, que você concorde ou não. Você tem todo direito de discordar, mas você vai receber um pensamento que vai te levar a pensar também, e não a não pensar, não a se emburrecer, mas a se enriquecer. Então, eu acho que isso daí vai poder continuar acontecendo no Cinezap, porque nós recebemos todo tipo de material, e quem faz o uso do material somos nós, através da edição. A edição não vai mudar nada, a edição vai continuar sendo feita pelo autor. Nós vamos ter um editor, nós vamos editar o filme, e vamos editar como a gente quer. Vai cortar, vai fazer o que quer. E aí, vai nascer um novo tipo de cinema, que a circulação é mais fácil, e é um cinema que vai te levar a uma outra reflexão. Eu gostei muito dessa ideia que eu tive e que eu vou fazer. E acho que isso que você citou do Brian de Palma, Spike Lee fez agora com a Guerra do Vietnã, ${ }^{6}$ em que ele mostrou os americanos que vão ao Vietnã, e veem a tragédia que eles vivem e a tragédia que eles provocam. Eles olham a guerra de outro ponto de vista, o que é muito interessante. Eu gostei muito.

Lucas: Silvio, legal que você trouxe essa questão de que a gente recebe temas. Se a gente se propor a pensar quantos temas nós recebemos no dia a dia, teremos um trabalho e tanto. No entanto, eu estou lembrando um pouco "O Anjo da História" [Paul Klee], onde nós vemos uma cadeia de acontecimentos, ele é uma catástrofe única, que acumula incansavelmente ruína sobre ruína e dispersa sobre seus pés, sobre nossos pés. E eu estou lembrando isso, uma citação que você usa do Walter Benjamin, no Utopia e Barbárie, e dialoga um pouco com essa definição dos temas, e eu queria que você falasse um pouco. Tem alguma coisa semelhante, alguma relação entre a definição de um tema na década de 70 , ou a definição de um tema para um filme nos anos 2020 ?

Silvio: Não, eu acho que, na verdade, é o que eu falei: cada época gera uma ética, uma estética, e uma técnica. Eu acho que, em 2020, a problemática é diferente da luta contra a ditadura, ela é diferente de 1980, quando eu fiz o JK, ela é diferente de quando eu lancei o Jango em 84, ela é diferente de

$6 \quad$ Trata-se do filme $D a 5$ Bloods (Spike Lee, 2020) (NdE). 
98, quando eu fiz o Marighella, e ela é diferente quando você encara o governo Bolsonaro. Eu acho que em alguns pontos de vista está havendo um empobrecimento da história, né? Quando você teve a Constituinte do Brasil em 88, alguns deputados da esquerda reclamavam do Congresso Brasileiro, da qualidade dos deputados. O Dr. Ulisses Guimarães dizia: "Vocês vão ver o próximo Congresso que vem aíl” E agora, aquele Congresso de 88 é muito melhor do que o que está aí hoje. O que está aí hoje é uma loucura, entendeu? E eu, a essas alturas, eu não sei o que que virá em 2040. Agora, nós temos que nos adequar a cada época, e não baixarmos a guarda, e continuar lutando. Esse Congresso que está aí, ele é muito ruim, mas é com ele que você vai fazer as lutas populares para lutar por dias melhores, entendeu? E cada momento é um momento, cara... Quem imaginou a gente, hoje, defendendo o Supremo Tribunal Federal? Estamos defendendo, né? Ele é complicado? Ele é complicado, mas ele é melhor do que a ditadura que o Bolsonaro propõe. Então, a gente está dentro disso, dessa luta. E a gente está dentro dessa luta, aliado com tudo o que existe na politica brasileira contra o Bolsonarismo, contra o terraplanismo, contra o negacionismo, né? Nós estamos num momento de enfrentamento com a barbárie. O que eu disse no Utopia e Barbárie segue valendo. Utopia e barbárie se alternam no poder. Você tem, durante a Segunda Guerra mundial, a barbárie; você tem os campos de concentração, em que morrem 6 milhões de judeus. Durante a guerra morrem 60 milhões de pessoas, e você termina a guerra com uma utopia, que é a abertura dos campos de concentração, e com uma barbárie, que é a bomba de Hiroshima e Nagasaki, que matam, num dia, 150 mil pessoas. Então, você termina a guerra com uma utopia e com uma barbárie e vai caminhar em direção a uma utopia. E o mundo pós-Segunda Guerra mundial é o mundo do jazz, dos existencialistas, dos beatniks, das calças jeans, da Twiggy, dos Beatles. É um mundo muito melhor do que o que tinha antes. Depois, ele vai virar, aqui no Brasil, numa puta ditadura. Então, nós vamos viver de 64 a 84 uma ditadura, lutando contra ela. Quando ela acaba, outra utopia. Aí, a gente vai para "Coração de estudante", com Milton Nascimento, vai para o mundo legal, pinta outra barbárie, que é a AIDS, que é a "pandemônia" dos anos 80; as pessoas morriam de AIDS, eu perdi muitos amigos; minha geração inteira morreu, e não tinha cura. Você saber, naquele momento, que você tinha AIDS, era saber que você estava condenado à morte, em 6 meses você ia morrer. Não tinha nenhum remédio. Hoje, você pode encontrar aí a AIDS e sabe que vai viver 30 anos, entendeu? Então você vai vivendo essas coisas de uma forma alternada. E o mundo é assim. A gente hoje está vivendo essa "pandemônia", e a gente jura que vai sair daqui, todos vamos sair melhores. E aí, de repente, a gente descobre os garotos do Leblon comemorando e brigando com a Guarda Municipal, que foi pedir a eles para manter o isolamento. E aí é complicado. Mas eu acho que o Walter Benjamin, que é um grande pensador, é maravilhoso, era meio deprimido. Ele era uma pessoa meio deprimida, meio negativista. Tanto que ele, quando foge da Alemanha para a Espanha, na fronteira com a França, se suicida porque acha que vai ser preso. Então, ele nem deu a ele mesmo a chance de sair vivo daquela história, ele preferiu encarar a morte ali. Aqui no Brasil, a gente tem um outro caso parecido, que foi o Stefan Zweig. Eu não sei se vocês conhecem o Stefan Zweig, que era um grande escritor austríaco; ele 
era judeu, ele era um dos maiores escritores do mundo. Escrevia, fez muita coisa para o cinema. Muitos livros dele foram adaptados e viraram grandes best-sellers, viraram filmes grandiosos, maravilhosos. E ele era um pacifista, até a última gota. Ele era amigo do Romain Rolland, era amigo dos grandes pensadores da época. Quando vem a Segunda Guerra mundial, ele vem morar no Brasil, ele vai morar em Petrópolis. E aí vem a Segunda Guerra mundial, e o Romain Rolland pede para ele apoiar o esforço de guerra contra o nazismo. Ele é judeu, mas ele era antibelicista, desde a Primeira Guerra mundial, em que ele jurou que nunca mais ia querer viver uma outra guerra. E ele não apoia, ele rompe com os amigos dele, intelectuais e europeus que vão apoiar a luta contra o nazifascismo. Ele se suicida e morre em Petrópolis. Ele, e a mulher dele - o que é uma história de amor meio confusa também. Ela secretária dele, ele vai viver com ela, e os judeus não podem se suicidar. Então, para ele não se suicidar, ela aplica o veneno nele, depois aplica nela e os dois morrem, morrem juntos. Uma história muito forte. Tem um livro do Alberto Dines (1981) sobre isso que você tem que ler, que é muito interessante. ${ }^{7} \mathrm{Eu}$ quero fazer um filme sobre isso.

$$
[\ldots]
$$

Jorge: Silvio, aí voltando um pouco agora, sobre o Cinezap, como que a gente poderia pensar o trabalho com acervo, com arquivos cinematográficos mesmo e, por outro lado, esse acervo do imediato, permanente, que é o Whatsapp? Como é que se trabalha, num caso e no outro, para construir um documentário, construir uma narrativa? Será que existe uma diferença fundamental, ou não?

Silvio: Não, não... Eu me lembro quando eu trabalhei com o Chris Marker em 73, eu tinha 23 anos. Ele apareceu um dia na sala de montagem, com um folheto do protótipo de uma máquina que você poderia jogar lá dentro as imagens em Super-8, 8, 16, 35... Você juntava tudo, montava, e depois formatava num formato único, e fazia um filme. Isso era o sonho da minha geração, em 73, porque ou você trabalhava com 8 ou com Super-8, com 16, com $35 .$. Era uma tecnologia muito complicada. Hoje em dia, esse problema não existe. Você joga tudo dentro do computador, você consegue um programa de edição - você pode comprar um sofisticado ou pode conseguir gratuitamente um programa bom e de graça ou você pode fazer como esses meninos fazem e pirateiam cópia de programa, entendeu? Você pode tudo! Você pega um programa de edição, você junta todo o material e você edita. O zap é um suporte, ele não é um fim em si mesmo. O zap é o suporte pelo qual eu estou guardando material. Então, eu estou guardando tudo em zap, porque chega para mim em zap, facilita a minha vida. Eu posso sofisticar esse trabalho, juntar com o que me chega também por e-mail. Por e-mail vai chegar, inclusive, com uma definição e uma qualidade melhor, porque a resolução do e-mail é melhor do que a resolução do zap. E aí você pode reduzir o do e-mail, jogar para o zap e formatar; você pode pegar o do zap, jogar para o e-mail e formatar. Ele vai ter

$7 \quad$ Ver também o filme Stefan Zweig: Adeus Europa (Maria Schrader, 2017) (NdE). 
uma limitação de ampliação, porque o zap tem pouca definição de imagem, então você não vai poder jogar aquela imagem em cinemascope, mas já já, vão surgir as tecnologias que vão te permitir transferir o zap para cinemascope sem perda nenhuma de qualidade. E aí, o problema se resolveu, entendeu? Eu, quando fiz o Glauber Rocha [Glauber, o filme], em 2004, ia ampliar o filme... Aqui no Brasil, a ampliação era cara e ruim. Nos Estados Unidos, custava 25 mil dólares, e era cheia de limitações. O cara só te entregava uma cópia. Se você quisesse fazer a outra cópia, ele ficava com o negativo. Se ele quisesse fazer a cópia para 35, se você quisesse fazer a segunda cópia custava tanto e mais tanto. Era uma coisa caríssima e dificil. E, naquela época, eu fui fazer o Glauber em 2004 - o Glauber saiu em 2004, no começo do ano. Ele ficou pronto em 2003, era governo Lula e aí, no começo, o dólar estava lá em cima, estava 4. Ele tinha saltado de 1 para 2 no governo Fernando Henrique, de 2 para 4. Então, uma cópia custaria 100 mil reais. Falei: "Impossivel fazer!". Eu arranjei um cara aqui no Rio, chamado Daniel Leite, que era um cara que eu encontrava na livraria. Ele vinha com umas conversas malucas de algoritmo, naquela época, eu estou falando em 2004! Algoritmo a gente fala dele hoje, em 2020. Ele já falava isso em 2003. E ele me falou, sei lá com 10 ou 15 mil reais, ele me ampliaria o filme. Ele foi maluco de topar fazer, e eu fui maluco de aceitar. Botei a grana na mão dele, e o que que ele fez? A diferença da imagem do negativo, que são fotogramas - o negativo é um fotograma, uma sucessão de fotografias que vão fazendo um movimento avançado. Cada uma vai mudando o movimento em relação à outra. Quando você faz uma projeção contínua, você tem a ilusão do movimento. Isso se chama persistência retiniana, que é o princípio do cinema. O videotape não tem o negativo. O videotape é uma fita magnética em que os frames vêm entrelaçados. O que que ele fez com esse tal desse algoritmo? Ele desentralaçou o negativo, e botou fotograma por fotograma, transformou o frame do vídeo numa imagem fixa, pegou uma lente muito boa, que pertencia ao Chico Moreira, que emprestou uma câmera ótima para ele, uma tela boa, fotografou aquelas imagens e recriou, no vídeo, o princípio do cinema. E aí, com isso, ele fez a ampliação do Glauber, muito mais barato do que eu pagaria se eu fizesse nos Estados Unidos! E dois malucos: um que acreditou, e outro que fez. E deu certo, entendeu? Então, eu te digo que, com o Cinezap, a gente vai conseguir fazer isso também. Depois, eu quero uma cópia dessa fita porque eu nunca falei disso!

Jorge: Silvio, eu estava pensando também pelo outro lado da questão, em relação à construção do argumento. No caso do zap, quando se tem essa diversidade enorme...

Silvio: É mais difícil... É mais dificil porque quanto mais material você tem, mais confuso fica. Você fica, você chega num momento em que você se perde. Você tem tanto material que você não sabe por onde vai. Aí o que que você faz? Você abandona. Você tem que saber ser seletivo, quer dizer, você está tocando num problema que é fundamental, que é o da criação. Quer dizer, o que que vou criar com tantas imagens? Isso dai é um problema da distopia, né? Na verdade, se você pega, por exemplo, o Fahrenheit [Fahrenheit 451], do Ray Bradbury, que o Truffaut filmou - eu não sei se você viu Fahrenheit... 
Você deve ter assistido... Ele acredita que a distopia do futuro é a queima de livros. Os livros vão ser proibidos, e as pessoas não vão mais poder ler. Então, ele junta um grupo de pessoas que se dispõem a decorar livros para guardar essa memória para o futuro, né? Ele, o Truffaut, e o Bradbury, estão pautados pelo passado. Eles estão pautados pelo Nazismo, que queimava livros em praça pública. Eles estão pautados pela Inquisição. Eles não estão pautados pelo futuro. Qual é a distopia de hoje? Você tem tanta oferta, que a gente não se encontra no mesmo livro. A gente é pautado pela grande mídia. Se eu te perguntar, o que que você está lendo, você está lendo um cara que a grande mídia te recomendou, o Lucas está lendo outro, o Alan está lendo outro... Por quê? Porque a gente não tem um ponto de convergência. Quem nos pauta hoje é a grande mídia, entendeu? Então, essa é a distopia. Você vai numa livraria hoje, você tem tanta oferta de tanta coisa, que é difícil você escolher. É exatamente a antítese do que o Truffaut imaginou que seria o futuro. Então, esse problema que você está me colocando é o problema de você fazer um filme hoje em dia, em que você tem tanta oferta que você fica sem caminho, você não tem uma pauta. Se eu te der 2 horas de material, você edita um filme de 10 minutos tranquilamente. Se eu te der 100 horas, você vai se perder. Esse é o problema. Mas eu acho que aí vem a questão autoral. Você tem que dizer: "Não, o problema que eu quero trabalhar é esse. O que eu vou trabalhar é a pandemia. O que eu vou trabalhar é a cabeça das pessoas flutuando à medida que o tempo passa...". Então eu recebi hoje gente super triste, gente muito alegre, gente muito feliz, muitas brincadeiras... E aí, eu vou juntar tudo isso, e vou trabalhar os sentimentos que flutuam à medida em que a gente vai ficando preso. E isso tem uma coisa de época também, né? Eu não sei se você viu um filme do Chris Marker chamado L'Ambassade, que é muito bom. É um Super-8 que ele fez, ele usa o Super-8 como linguagem, né? O Chris é um cara inventor de linguagens, e ele sempre trabalhou a tecnologia como linguagem. Então, em 73, quando teve o golpe do Chile - teve o golpe de estado do Chile, que derrubou o Salvador Allende e que colocou Pinochet no lugar. Naquela época, as pessoas filmavam em 16 ou 35, só os alternativos faziam Super-8. $\mathrm{O}$ vídeo ainda era muito embrionário, e as pessoas não acreditavam muito que haveria vídeo no futuro, que o futuro da televisão seriam os filmes em Super-8. Aí o que que o Chris Marker fez? Ele pegou uma camereta Super-8 que ele tinha, juntou um casarão de amigos dele, e colocou dentro de uma casa como se fosse uma embaixada no Chile. E aí, um cara que foi no exterior, comprou uma câmera e, já que ele estava exilado naquela embaixada, ele vai aprender a filmar e começa a filmar as pessoas da embaixada. E aí ele erra o zoom, faz fora de foco, com foco, faz todas aquelas besteiras que um amador faz... E vai filmando o tédio da embaixada e as pessoas todas, no começo, solidárias, alegres, juntas e tal e, no final, todo mundo já de saco cheio, ninguém aguentando mais nada e tal... E aí, todo mundo assiste o filme o tempo todo achando que ele está falando do Chile no Pinochet, do golpe de Estado. E o último plano do filme é a Torre Eiffel! Então, ele não está falando de 73, ele está falando de 78 e a eleição do Mitterrand na França, entendeu? Então, ele fez uma ficção científica maravilhosa, usando o Super-8, tecnologia como recurso de linguagem e estética. 
Lucas: Então, Silvio, para a gente ir encerrando... Você fala, então, dessa nova forma de captação de material para a produção cinematográfica, né, como o Cinezap. Você pensa também numa forma de exibição nova para além das telas tradicionais do cinema?

Silvio: Sim, sim... Eu acho que o cinema, a tela tradicional, a menos que surja logo uma vacina segura, eu duvido que os 4 que estão nessa sala topem entrar numa sala de cinema e ficar 2 horas dentro, assistindo um filme... mesmo de máscara! Imagina tua cara, se o Alan soltar um espirro ali dentro... Entendeu? Então, é horrivel cara, é horrivel! A gente vai para esse mundo, e a gente já estava vivendo um problema muito sério com o cinema político: é que os cinemas migraram para os shoppings, e ninguém vai ao shopping para ver cinema politico. Ninguém mais vai ver Jango, JK, no cinema de shopping como foi ver. Eu fiz um milhão de espectadores com Jango. Duvido que hoje eu fizesse. Hoje, o Miguel Faria não fez com Vinícius, entendeu? Esses grandes filmes documentários contemporâneos, um puta documentário do Brasil faz 250 mil espectadores. Pelé não faz 1 milhão de espectadores, entendeu? ${ }^{8}$ Então, eu acho que vamos ter que buscar novos suportes, e eu acho que esse suporte do celular, da televisão, eu não acho que vá terminar o espetáculo coletivo, essa coisa coletiva vai continuar existindo, mas primeiro a gente vai precisar recuperar a nossa segurança em relação à saúde e, depois, em relação à ocupação dos espaços. Mas, se nós todos aqui assistirmos juntos um filme no Zoom, ${ }^{9}$ depois a gente pode conversar, estamos todos dentro da mesma sala sem correr risco. Tem solução. Nós, nunca vamos perder a noção do coletivo. O Milton Santos disse isso. Essa é a frase para encerrar a entrevista com chave de ouro. Eu perguntei: "Professor, o senhor acha que a gente vai poder cada um trabalhar na sua casa, com os meios que a gente tem?" Naquela época, eu falei em $f a x, 2007$ ainda tinha fax, hoje ninguém mais precisa de fax. Tu passa um fax por Whatsapp, você manda um documento por internet - documento com valor de documento, você faz uma assinatura eletrônica! Então, você não precisa mais ter fax, não precisa nada dessas subtecnologias. Eu perguntei a ele sobre home office em 2007, aliás, não: 2000. Eu disse 2007, mas ele morreu em 2001. "Professor, o senhor acha que a gente vai poder cada um ficar na sua casa, trabalhando sozinho e tal?" Sem a colmeia, o homem não cria. O homem precisa da colmeia para exercitar o pensamento. [...].

\section{Referências bibliográficas}

Benjamin, Walter. 2009. Passagens. Belo Horizonte e São Paulo: Ed. da UFMG / Imprensa Oficial do Estado.

$8 \quad$ O documentário Pelé deve sair em breve, na plataforma Netflix (23 fev. 2021). Aqui, Silvio está se referindo ao documentário de 1974 de Luiz Carlos Barreto, Isto é Pelé (NdE).

9 Aplicativo de videoconferência, dos mais utilizados no atual contexto de isolamento social devido à pandemia, segundo dados da Sensor Tower, uma startup de dados sobre uso de aplicativos e tendências financeiras (NdE). 
"Biografia". Caliban Produções Cinematográficas. Disponivel em: http://caliban.com.br/biografia/.

Bradbury, Ray. 2003 (1953). Fahrenheit 451. Rio de Janeiro: Editora Globo.

Dines, Alberto. 1981. Morte No Paraiso: A Tragedia de Stefan Zweig. Rio de Janeiro: Nova Fronteira.

Escorel, Eduardo. 2010. "Utopia e Barbárie - ilusões perdidas e esperança". Revista Piauí online. Disponivel em: https://piaui.folha.uol.com.br/utopia-e-barbarie-ilusoes-perdidas-e-esperanca/.

\section{Referências filmográficas}

2001: Odisseia no Espaço. Direção: Stanley Kubrick. Produção: Stanley Kubrick. EUA, 1968. Castro Alves - Retrato Falado do Poeta. Direção: Silvio Tendler, Produção: Caliban. Brasil, 1999.

Da 5 Bloods. Direção: Spike Lee. Produção: 40 Acres \& A Mule Filmworks; Rahway Road Productions. EUA, 2020.

Dedo na Ferida. Direção: Silvio Tendler, Produção: Caliban. Brasil, 2008.

Encontro com Milton Santos: O Mundo Global Visto do Lado de Cá. Direção: Silvio Tendler, Produção: Caliban. Brasil, 2006.

Fahrenheit 451 Direção: François Truffaut. Produção: Anglo Enterprises; Vineyard Film Ltd. Reino Unido, 1966.

Glauber o Filme, Labirinto do Brasil. Direção: Silvio Tendler, Produção: Caliban. Brasil, 2003.

Isto é Pelé. Direção: Luiz Carlos Barreto. Produção: Luiz Carlos Barreto Produções Cinematográficas; Rede Globo de Televisão. Brasil, 1974.

Jango. Direção: Silvio Tendler, Produção: Caliban. Brasil, 1984.

L'Ambassade. Direção: Chris Marker. Produção: Société pour le Lancement des OEuvres Nouvelles (SLON). França, 1973.

Marighella, Retrato Falado do Guerrilheiro. Direção: Silvio Tendler, Produção: Caliban. Brasil, 2001.

Memória do Aço. Direção: Silvio Tendler, Produção: Caliban. Brasil, 1987.

Nas Asas da Panam. Direção: Silvio Tendler, Produção: Caliban. Brasil, 2020.

No Ano do Porco. Direção: Emile de Antonio. Produção: Emile de Antonio Productions; Turin Film Productions. EUA, 1968.

Os Anos JK - Uma Trajetória Política. Direção: Silvio Tendler, Produção: Caliban. Brasil, 1980. Redacted. Direção: Brian de Palma. Produção: HDNet Films; The Film Farm. EUA, 2007.

Stefan Zweig: Adeus Europa. Direção: Maria Schrader. Produção: X-Filme Creative Pool; Idéale Audience; Maha Productions; Dor Film Produktionsgesellschaft. Áustria, Alemanha, França, 2017.

Utopia e Barbárie. Direção: Silvio Tendler, Produção: Caliban. Brasil, 2009.

Vinícius. Direção: Miguel Faria Jr. Produção: 1001 Filmes; 1001 Produções Artísticas. Espanha, Brasil, 2005. 


\section{In the Wings of the Pandemic: an Interview with Silvio Tendler}

Interview conducted online between June and July 2020. Silvio Tendler talks about the pandemic situation and the ways he found to remain active during this period of social distancing. Tendler is "inventing another cinema", based on the daily and tireless collection of innovative raw material, collected by means of the Whatsapp application: a form of cinematographic production that the filmmaker from Rio calls Cinezap, or cinema produced in times of pandemic "cinemic", as he also coins it. Tendler talks about the topics still to be treated, revealing details about his current cinema projects.

Keywords: cinema, lockdown, pandemic, Silvio Tendler, social distancing 